\title{
斜め遡上波による波打ち帯の沿岸方向流れ の解析
}

波が斜めに入射するときの平面 2 次元遡上波を，長波理論によって準 1 次元的に解析 する手法を示した．この数值解析により波打ち帯の沿岸方向流れの特性を調べ，底面勾 配・摩擦係数・入射波諸元の結果に及ぼす効果を検討した。その結果, 沿岸方向流れは 静水時汀線より岸側でも有意な大きさとなること, 平面流速べクトルは遡上時と流下時 で方向特性が異なることなよ゙, 波打ち帯での流体運動・漂砂運動を議論する上で基礎と なる知見が得られた。

Key Words : swash zone, obliquely incident wave, longshore current, shallow water equation, quasi-one dimensional analysis

\section{1. まえがき}

近年, 砕波帯を含めた波浪場・海浜流場の数值モデル が活発に研究されており，漂砂モデルと組み合わせて精 密な 3 次元海浜変形予測が可能となりつつある.しかし， 波打ち帯については波の遡上・流下に伴って没水・干出 を繰り返すため, 静水深を中心に水位が変動するとする 通常の波動運動の取扱いができない. そのために波打ち 帯の波・流れの場，それに伴う海浜変形の予測は，現在 未解明の課題の 1 つとなっている. 最近, Bodge-Dean ${ }^{1)}$ や Kamphuis ${ }^{2)}$ は，沿岸漂砂量が砕波点近傍のみならず 波打ち帯にも別の極大值を持つことを実験・現地観測か ら明らかにした．汀線の前進・後退には波打ち帯の漂砂 が大きく関与する. 本研究は, 汀線変化をも包括した海 浜変形の予測を行うことを最終的な目標とし，まず波打 ち帯の流体運動の特性を平面 2 次元の非線形長波方程式 によって明らかにしようとするものである.

周知のように汀線変化モデルは, 最近では各等深線の 変化まで予測するモデルへと精密化されているが3), 沿 岸漂砂量の非一様性からマクロな地形変化を予測するも のであって, 波打ち帯における時間変動する流体力と漂 砂の過程を議論するものではない. 3 次元海浜変形モデ ルは, 前述のように波打ち帯の変形予測に課題が残され ている.しかし，従来の波動場の計算から radiation stress を介して海浜流を求め漂砂の計算を行う手続きに 対して, 最近ではBoussinesq 方程式のような非線形波 動理論を用いて波動場と平均水位・海浜流場を同時計算 する手法が開発されている ${ }^{4)}$. 本研究の基礎式は非線形 長波方程式であり, 平均水位の上昇・波による流れと いった波の非線形性に起因する現象も表現できる．もち

\footnotetext{
* 正会員 工博 鹿児島大学助教授 工学部海洋土木工学科

（テ890＼cjkstart鹿児島市郡元 1-21-40）
}

ろん長波理論の限界はあり, 3 次元の地形変化を議論す るためには, 波の軌道流速の鉛直分布や戻り流れを含め た海浜流の鉛直分布の取り込みも必要で5)，砕波による 乱れや渦も考慮する必要がある.

本研究の計算領域は波打ち帯を含む砕波帯全域を対象 とした。これは斜め遡上波による汀線付近の沿岸方向流 れを求めるためには，砕波帯全域で形成される沿岸流を 計算する必要があるためである．砕波に伴う波高減衰を 表現するには, 運動量方程式中に砕波減衰項を導入する 方法もあるが ${ }^{4), 6)}$, 本研究では数值粘性項を導入する方 法によった．非線形長波理論では非線形性による波峰の 突立ちを減衰させるため，また離散化による数值振動を 抑えるためにも数值粘性項の導入が不可欠であるが，こ の方法はこれを積極的に利用したもので，HibbertPeregrine $^{7)}$ や Kobayashi et al. ${ }^{8)}$ によって 1 次元の砕波 後の波高減衰が表現できることが確認されている.

また，遡上波先端を自由境界として平面 2 次元で計算 することは計算時間が長大になるので，著者らは波向線 に沿って波を追跡することにより岸沖方向と沿岸方向の 運動方程式を分離して計算できる $\mathrm{Ryrie}^{9)}$ の方法を採用 した.この理論解析の概要と比較的急な斜面に対する $2 \cdot 3$ の計算結果については既に報告したが ${ }^{10)}$, 本研究 では, 前報の計算を精密化し広範な条件で計算を行って, 波打ち帯における沿岸方向流れの特性を明らかにする. さらに, 既往の波浪変形の実験結果との比較から計算結 果の実証性を検討する.

\section{2. 斜め遡上波の基礎方程式}

Ryrie $(1983)^{9)}$ は平面 2 次元長波を, 擬時間（pseudotime） $\hat{t}$ を導入し， $t, y 2$ つの独立変数を 1 つの独立変 数 $\hat{t}$ にまよめることによって，1 次元的に解析する手法 を示した.ここでは，この取扱いに従って遡上端を自由 境界とした平面 2 次元の遡上波を準 1 次元的に解析す 


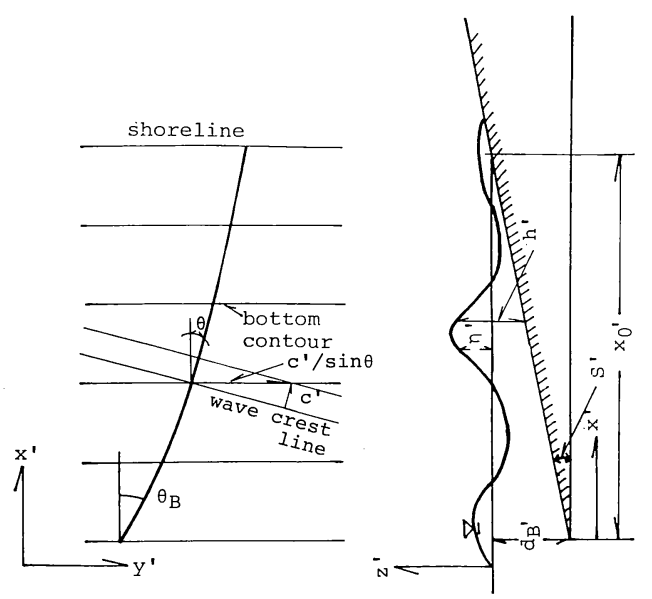

図一1 座標系

る.

図一1に示すように, 沖側端において $\theta_{B}$ の角度をもっ て入射する波峰の平行な波が，平行等深線を持つ勾配 $S^{\prime}$ の斜面上を伝播する時の汀線付近の運動を考える. 汀線に直角方向に $x$ 軸, 沿岸方向に $y$ 軸をとり, 静水 面を起点として鉛直上方に $z$ 軸をとる. 連続式および水 深方向に積分した $x, y$ 方向の運動方程式はそれぞれ次 式となる.

$$
\begin{aligned}
& \frac{\partial h^{\prime}}{\partial t^{\prime}}+\frac{\partial}{\partial x^{\prime}}\left(h^{\prime} u^{\prime}\right)+\frac{\partial}{\partial y^{\prime}}\left(h^{\prime} v^{\prime}\right)=0 \\
& \frac{\partial}{\partial t^{\prime}}\left(h^{\prime} u^{\prime}\right)+\frac{\partial}{\partial x^{\prime}}\left(h^{\prime} u^{\prime 2}\right)+\frac{\partial}{\partial y^{\prime}}\left(h^{\prime} u^{\prime} v^{\prime}\right) \\
& =-g h^{\prime} \frac{\partial \eta^{\prime}}{\partial x^{\prime}}-\frac{\tau_{b, x}^{\prime}}{\rho} \\
& \frac{\partial}{\partial t^{\prime}}\left(h^{\prime} v^{\prime}\right)+\frac{\partial}{\partial x^{\prime}}\left(h^{\prime} u^{\prime} v^{\prime}\right)+\frac{\partial}{\partial y^{\prime}}\left(h^{\prime} v^{\prime 2}\right) \\
& =-g h^{\prime} \frac{\partial \eta^{\prime}}{\partial y^{\prime}}-\frac{\tau_{b, y}^{\prime}}{\rho}
\end{aligned}
$$

上式中の'は次元量であることを示す．ここに $t^{\prime}$ は時 間, $g$ は重力加速度, $\tau_{b, x}^{\prime}, \tau_{b, y}^{\prime}$ はそれぞれ $x, y$ 方向の 底面せん断応力, $\rho$ は流体の密度である. $u^{\prime}, v^{\prime}$ は, そ れぞれ水深方向に平均した $x, y$ 方向の流速成分である. $h^{\prime}$ は斜面上の水深で, 静水面から測った水位 $\eta^{\prime}$, 沖側 端の静水深 $d_{B}^{\prime}$ および斜面勾配 $S^{\prime}$ と次式で結ばれる.

$$
h^{\prime}=\eta^{\prime}+\left(d_{B}^{\prime}-S^{\prime} x^{\prime}\right)
$$

これより,

$$
\frac{\partial \eta^{\prime}}{\partial x^{\prime}}=\frac{\partial h^{\prime}}{\partial x^{\prime}}+S^{\prime}
$$

底面せん断応力の $x, y$ 成分 $\tau_{b, x}^{\prime}, \tau_{b, y}^{\prime}$ は次式で表される.

$$
\begin{aligned}
& \tau_{b, x}^{\prime}=\frac{1}{2} \rho f^{\prime}\left|u^{\prime}\right| u^{\prime} \\
& \tau_{b, y}^{\prime}=\frac{1}{2} \rho f^{\prime}\left|u^{\prime}\right| v^{\prime}
\end{aligned}
$$

連続式（1）および式（5) を考慮して式（2），(3)
を書き直すとそれぞれ次式となる.

$$
\begin{aligned}
& \frac{\partial u^{\prime}}{\partial t^{\prime}}+u^{\prime} \frac{\partial u^{\prime}}{\partial x^{\prime}}+v^{\prime} \frac{\partial u^{\prime}}{\partial y^{\prime}}+g \frac{\partial \eta^{\prime}}{\partial x^{\prime}}+\frac{1}{2} \frac{1}{h^{\prime}} f^{\prime}\left|u^{\prime}\right| u^{\prime}=0 \cdots \\
& \frac{\partial v^{\prime}}{\partial t^{\prime}}+u^{\prime} \frac{\partial v^{\prime}}{\partial x^{\prime}}+v^{\prime} \frac{\partial v^{\prime}}{\partial y^{\prime}}+g \frac{\partial \eta^{\prime}}{\partial y^{\prime}}+\frac{1}{2} \frac{1}{h^{\prime}} f^{\prime}\left|u^{\prime}\right| v^{\prime}=0 \cdots \cdots
\end{aligned}
$$

入射波高 $H^{\prime}$ ，入射波周期 $T^{\prime}$ を用いて，次のような 無次元化を行う.

$$
\begin{aligned}
& u=\frac{u^{\prime}}{\sqrt{g H^{\prime}}} ; \eta=\frac{\eta^{\prime}}{H^{\prime}} ; h=\frac{h^{\prime}}{H^{\prime}} ; t=\frac{t^{\prime}}{T^{\prime}} ; \\
& x=\frac{x^{\prime}}{T^{\prime} \sqrt{g H^{\prime}}} ; c=\frac{c^{\prime}}{\sqrt{g H^{\prime}}} ; f=\frac{1}{2} \sigma f^{\prime} ; \\
& S=T^{\prime} \sqrt{\frac{g}{H^{\prime}}} S^{\prime} ; d_{B}=d_{B}^{\prime} / H^{\prime} ; \sigma=T^{\prime} \sqrt{g / H^{\prime}} ;
\end{aligned}
$$

上式で最後 3 つの無次元量の意味は次のとおりであ る.まず, $S$ はsurf similarity parameter $\xi$ で表せば $S$ $=\sqrt{2 \pi} \xi$ あ゙り, また $d_{B}$ は沖側境界での比水深の逆数 に相当する. また $\sigma / h$ は $L^{\prime} / h^{\prime}$ となり, 水深・波長比の 逆数となる.

沿岸方向に地形・波の条件が変化しない場合を対象と しているので, 沿岸方向に $C^{\prime} / \sin \theta($ Snell の法則から $C_{B}^{\prime} / \sin \theta_{B}$ に等しい) で移動する観測者から見ると現象 は $y$ 方向に無関係となる. すなわち, 次式のような擬時 間 $\hat{t}^{\prime}$ (psuedotime) を導入すれば， $t$ と $y$ の 2 つ独立変 数は 1 つにまとまる.

$$
\hat{t}^{\prime}=t^{\prime}-\frac{\sin \theta_{B}}{C_{B}^{\prime}} y^{\prime}
$$

ここでは, 入射角 $\theta_{B}$ は十分小さいと仮定する.すなわち,

$$
\epsilon=\frac{\sin \theta_{B}}{C_{B}^{\prime}} \sqrt{g H^{\prime}} \text {. }
$$

を微小パラメターとして以下の解析に用いる. 入射角 $\theta_{B}$ が微小であれば, 沿岸方向流速 $v$ は $u$ に比べ十分小 さく, また $y$ 方向の現象変化の長さスケールは $x$ 方向 に比べて十分大きいから, 次の様な拡大・縮小変換を導 入し, 無次元化を行った後の諸量のオーダーを揃えてや る.

$$
v=\frac{v^{\prime}}{\epsilon \sqrt{g H^{\prime}}} ; y=\frac{\epsilon y^{\prime}}{T^{\prime} \sqrt{g H^{\prime}}}
$$

この時, pseudotime の無次元表示は

$$
\hat{t}=t-y \text {. }
$$

となり $\left(\hat{t}=\hat{t}^{\prime} / T\right)$, 独立変数は次のように変換される.

$$
\frac{\partial}{\partial t}=\frac{\partial}{\partial \hat{t}} \quad \frac{\partial}{\partial y}=-\frac{\partial}{\partial \hat{t}} \text {. }
$$

ここで,

$$
\begin{aligned}
& \frac{\partial}{\partial t^{\prime}}=\frac{1}{T^{\prime}} \frac{\partial}{\partial t}=\frac{1}{T^{\prime}} \frac{\partial}{\partial \hat{t}} \quad \frac{\partial}{\partial x^{\prime}}=\frac{1}{T^{\prime} \sqrt{g H^{\prime}}} \frac{\partial}{\partial x} \\
& \frac{\partial}{\partial y^{\prime}}=\frac{\epsilon}{T^{\prime} \sqrt{g H^{\prime}}} \frac{\partial}{\partial y}=-\frac{\epsilon}{T^{\prime} \sqrt{g H^{\prime}}} \frac{\partial}{\partial \hat{t}} \cdots \cdots \cdots
\end{aligned}
$$

を考慮すると, 式 $(1),(7),(8)$ の無次元形として 
次式が誘導される.

$$
\begin{aligned}
& \frac{\partial h}{\partial \hat{t}}+\frac{\partial(u h)}{\partial x}=\epsilon^{2} \frac{\partial(v h)}{\partial \hat{t}} \cdots \cdots \ldots \ldots \ldots . . . . . . . . \\
& \frac{\partial u}{\partial \hat{t}}+u \frac{\partial u}{\partial x}+\frac{\partial h}{\partial x}+S+\frac{f u|u|}{h}=\epsilon^{2} v \frac{\partial u}{\partial \hat{t}} \\
& \epsilon\left\{\frac{\partial v}{\partial \hat{t}}+u \frac{\partial v}{\partial x}-\frac{\partial h}{\partial \hat{t}}+\frac{f|u| v}{h}\right\}=\epsilon^{3} v \frac{\partial v}{\partial \hat{t}}
\end{aligned}
$$

$\epsilon^{2}$ 以上の高次項を無視すれば，式（16)，(17）の右 辺は 0 となり，汀線に直角に入射する長波の式と同型に なる. よって入射角をもって遡上する場合も $u$ と $v$ と の相互干渉効果は考慮しなくてて良いことになる. 式 (18) を $O(\epsilon)$ の範囲で考えると,

$$
v_{i}+u v_{x}-h_{i}+\frac{f|u| v}{h}=0 \cdots
$$

が得られる. 数值計算の基礎式は式（16），(17）で右辺 を 0 と置いたもの，および式（18）の右辺を 0 之置いた 式 (19) である.これらは右辺が左辺より $O\left(\epsilon^{2}\right)$ 小さく, 入射角 $\theta_{B}$ が小さいという理論の前提条件は, 式 (11) の $\epsilon$ が 2 次のオーダーで無視できることに使用されてい る.したがって実際の $\theta_{B} に$ 関する制約は厳しいもので はないことがわかる。

本研究では変数の無次元化を式（9）とすることによ り, 式 (16)，(17）に対応する特性曲線表示の不変量が 通常の $\pm u+2 c$ となるよう改良した（Ryrie の原論文で は不変量が $\pm u+2 c \pm \dot{t}$ 之なり，その物理的特性が考元 にくい). また原論文中のいくつかの展開の見透しの悪 い点やオーダー評価に関する誤りも修正した。さらに， Ryrie は沿岸流速 $v$ に対する式（19）を,

$$
h\left(v_{i}-h_{i}+u v_{x}\right)+v\left\{h_{i}+(h u)_{x}\right\}+f|u| v=0 \text {. }
$$

之書き直し，次式のような保存型の表示式を得た。

$$
R_{i}+S_{x}=-f|u| v
$$

$$
\text { ここに, }
$$

$$
R=h v-\frac{1}{2} h^{2}, \quad S=h u v
$$

である。

しかし，実際に上式で計算を行ってみると，遡上波先 端近くでは水深 $h$ および $u$ が 0 に近づき， $v$ の算定精度 が悪くなることがわかった．本計算では式（19）を用い て計算を行うことにした。

\section{3. 数值計算の手順}

1 波長の波を表現するために少なくとも 20 個程度の 格子が必要であり，岸沖方向の計算領域を 100 分割とし た. 数值計算の安定条件として時間刻み $\Delta t$ 之空間刻み $\Delta x$ の間には $\Delta x / \Delta t>\left|u_{m}\right|+c_{m}\left(\left|u_{m}\right|, \quad c_{m}\right.$ はそれぞれ計算 領域内で予想される水平流速の絶対値の最大值, 波速の 最大值）を満たす必要がある．さらに時々刻々の遡上波
先端の決定に関しても， $\Delta t, \Delta x$ に対する別途の安定条 件が必要であり ${ }^{7)}$, 検討の結果， $\Delta t$ は波の周期の 4000 分の 1 とした. 初期条件は計算領域のすべての点で静水 状態を仮定し, $x, y$ 方向流速を 0 とした. 沖側境界条件は次式で与えられる。

$$
h=d_{B}+\eta_{i}(t)+\eta_{r}(t), \text { at } x=0
$$

ここに, $\eta_{i}, \eta_{r}$ は沖側端での入射波, 反射波の時間波 形である． $\eta_{i}$ は与えられた波高，周期，水深から算定 されるUrsell数に応じてストークス波またはクノイド 波で与えた。沖側境界の位置は, 沿岸方向流速の時間平 均值 $V$ を 0 で与えることができるよう, 砕波点より約 1 波長程度沖方に設定した。 $\eta_{r}$ は後退特性曲線 $\beta=-u$ $+2 c=-u+2 \sqrt{h}$ より, 次式で与えられる ${ }^{8)}$.

$$
\eta_{r}(t)=\sqrt{d_{B}} \beta(t) / 2-d_{B}, \quad \text { at } x=0
$$

$u$ の沖側境界条件は $\beta$ 亡 $h$ から自動的に定まる. $v$ の沖 側境界条件は $u$ の沖側境界値に $\tan \theta$ を乗じた形で与え た.

岸側端については計算ステップの進行とともに遡上波 先端の位置 $x_{s}$ を定める必要がある.これは汀線での運 動学的条件之水深 0 の条件より, 次式で与えられる.

$$
\frac{d x_{s}}{d t}=u, h=0 \quad \text { at } x=x_{s}(t)
$$

数值計算を行う上では, 汀線位置は $h=0$ ではなく, 微 小水深 $\delta$ を定め, $h_{j, n}>\delta, h_{j+1, n} \leq \delta$ となる $j=s$ の節点 を見出すことによって決定される ${ }^{7)} . \delta$ の大きさの設定 によって, 時間とともに変動する遡上波先端位置が少し 異なってくるが， $\delta$ を数種類に変えた予備検討の結果, $\delta^{\prime}=0.1 \mathrm{~cm}$ として計算した. 本解析では平面 2 次元波 を, 式（10）で示した沿岸方向に $C^{\prime} / \sin \theta$ の速度で進 む移動座標系の導入によって, 1 次元解析で計算するこ とになる. 基礎式 (16)，(17）については変数を保存型 に直し，数值粘性項を含む Lax-Wendroff スキームで 計算した．沿岸方向の運動方程式については前述のよう に保存型の式 (22) では不都合が生じるので元の式 (19) を風上差分法で計算した。

\section{4. 計算結果並びに考察}

\section{（1）予備的検討}

本研究の目的は波打与帯における沿岸方向流速 $v$ の特 性を明らかにすることにあるから，計算結果の妥当性は この領域での $v$ に関する実験結果との比較によらねばな らない．しかし，現在のところこれに関する信頼できる

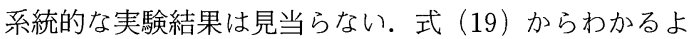
うに, $v$ は水深 $h$ 之岸沖方向流速 $u$ 之に関係づけられる から，vの值が妥当であるためにはまず， $h$ と $u$ に関す る計算結果が正しいものである必要がある。そこで斜面 上を伝播する波の波高変化に関する信頼できる既往の 
表一1 検討に用いたデータセットの実験条件

\begin{tabular}{l|ccccccc}
\hline & $\mathrm{S}^{\prime}$ & $\begin{array}{c}\mathrm{H}_{0}{ }^{\prime} \\
(\mathrm{m})\end{array}$ & $\begin{array}{c}\mathrm{T}^{\prime} \\
(\mathrm{s})\end{array}$ & $\begin{array}{c}\mathrm{d}_{\mathrm{B}}{ }^{\prime} \\
(\mathrm{m})\end{array}$ & $1 / \mathrm{d}_{\mathrm{B}}$ & $\xi$ & $\mathrm{d}_{\mathrm{B}} / \sigma$ \\
\hline $\begin{array}{c}\text { Kamphuis } \\
(1991)\end{array}$ & $1 / 10$ & 0.124 & 1.15 & 0.55 & 0.225 & 0.408 & 0.435 \\
$\begin{array}{c}\text { Sato et a1. } \\
(1988)\end{array}$ & $1 / 20$ & 0.061 & 1.18 & 0.40 & 0.153 & 0.298 & 0.437 \\
$\begin{array}{c}\text { Stive-Wind } \\
(1982)\end{array}$ & $1 / 40$ & 0.159 & 1.79 & 0.70 & 0.227 & 0.140 & 0.314 \\
\hline
\end{tabular}

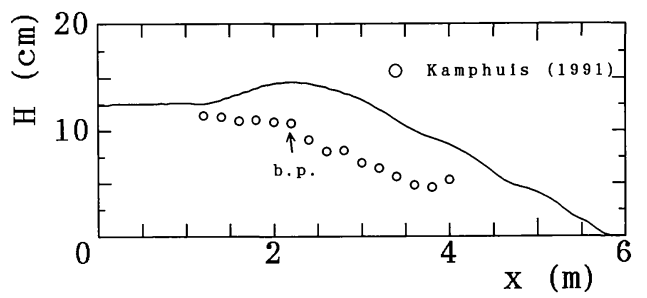

図一2 Kamphuis の実験結果と計算結果の比較
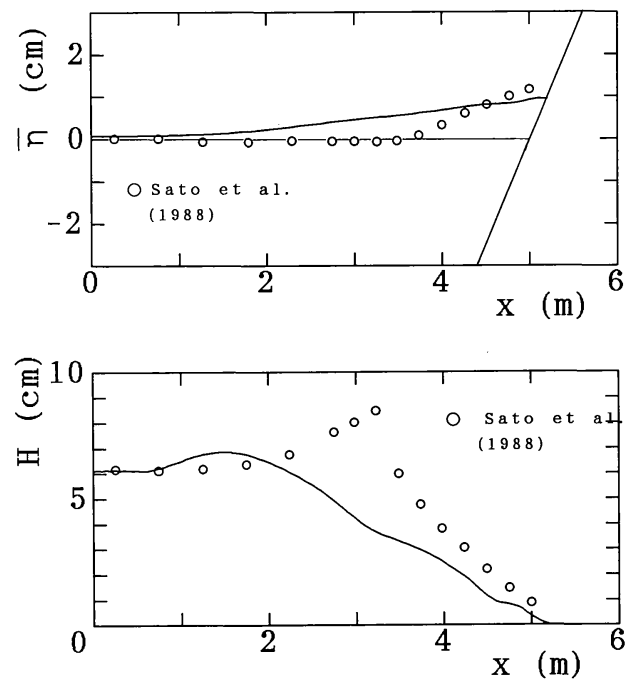

図一3 Sato らの実験結果と計算結果の比較

データセットを選び, 本計算結果と比較することにした.

第 1 は Kamphuis が, 平面水槽内で行った斜め入射波 の波高変化のデータである11). 彼は初期勾配として $1 / 10$ の一様斜面を砂で造成し，全部で 28 ケースの規則 波・不規則波を用いた実験を行っている．ただし，波高 変化のデー夕が公表されているのは不規則波を用いた 1 ケースのみで, この場合の一様水深部における入射角は $30^{\circ}$ である.この実験は移動床上のものであり, 砕波点 以前にも波高の減衰があるなど疑問もあるが，数少ない 平面 2 次元の実験データであり, 汀線付近の沿岸方向漂 砂量に関する興味深い結果も報告されているので, ここ で取り上げることにした。第 2 はS Sato ら ${ }^{12)}$ が $1 / 20$ の一 様勾配斜面上で行った規則波の実験結果のうちの Case-6の結果である. 第 3 はStive-Wind ${ }^{13)}$ による室 内実験結果の Test-1で，ここでは彼らが示した波形の 包絡線をもとにKobayashi ら ${ }^{14)}$ が読みとった結果を採
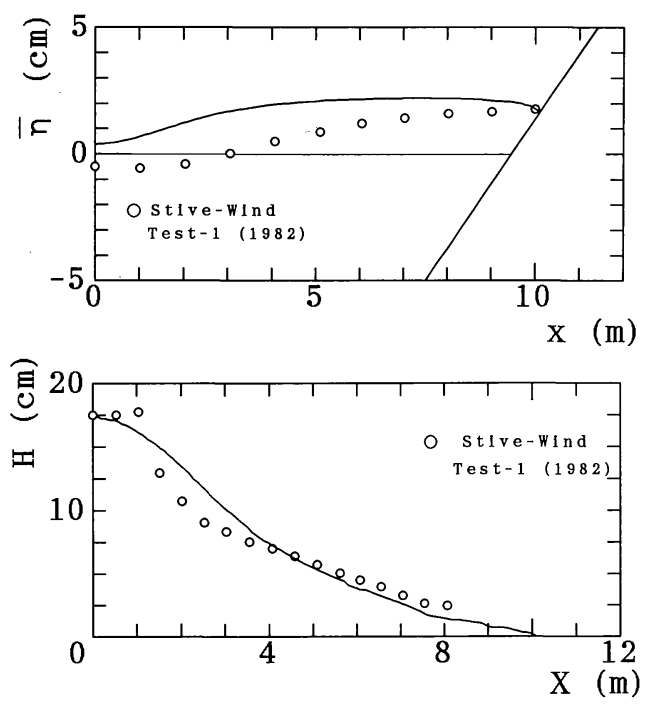

図一4 Stive-Wind の実験結果と計算結果の比較
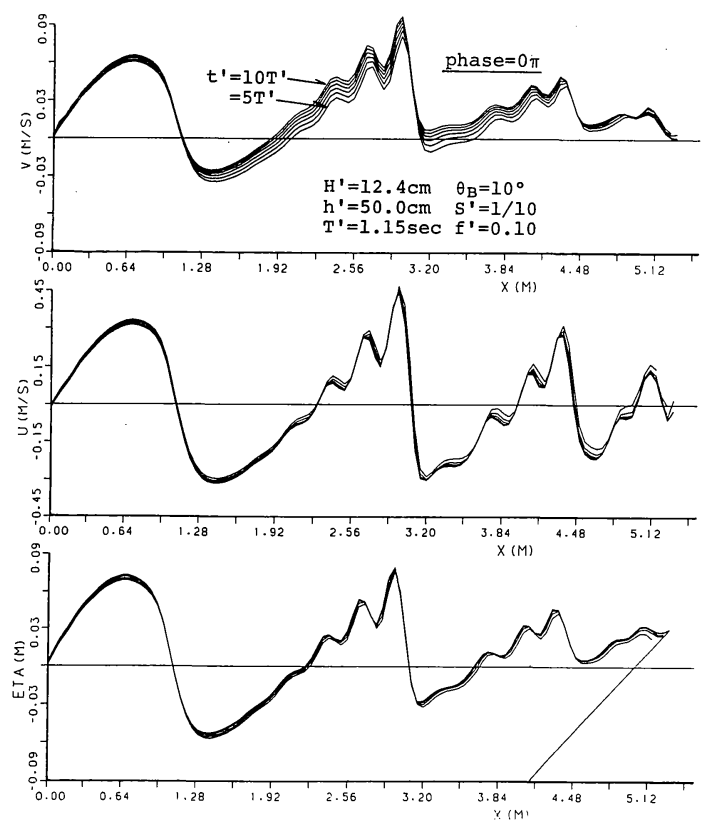

図一5 計算時間に伴う結果の変化

用した. Satoらおよび Stive-Wind の実験は直角入射 条件で行われている. 以上の 3 つの実験データの諸元と, 比水深 $1 / d_{B}$, surf similarity parameter $\xi$ および水深 ・ 波長比 $d_{B} / \sigma$ を表一 1 に示す.

計算における摩擦係数 $f^{\prime}$ の設定であるが， $f^{\prime}$ はもち ろんそれぞれの実験で用いた斜面の材質, 水理条件に よって決まるものである. 水口ら ${ }^{15)}$ は, 小型平面水槽内 に 4 種類の異なる材質の底面を設置して沿岸流速を測定 したところ, 結果に与える底面粗度の差は有意ではなく, 沿岸流速加ら逆算される $f^{\prime}$ として $0.032 \sim 0.052$ の值を 


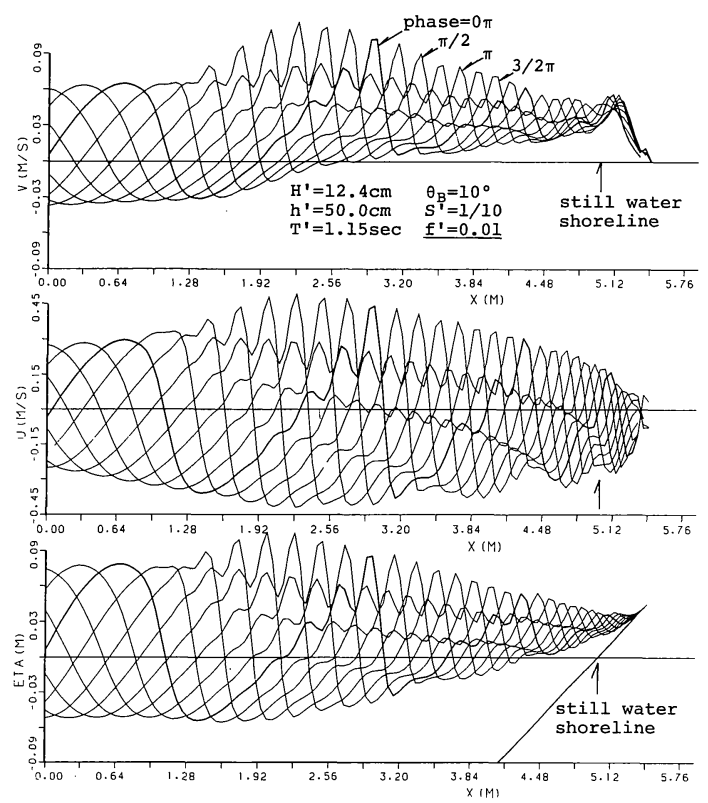

(a)

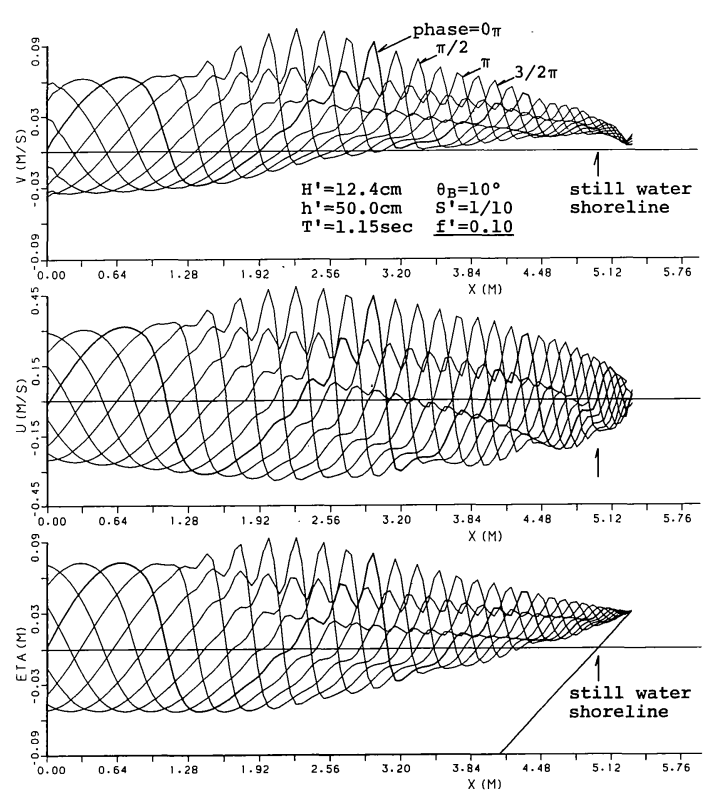

( b )
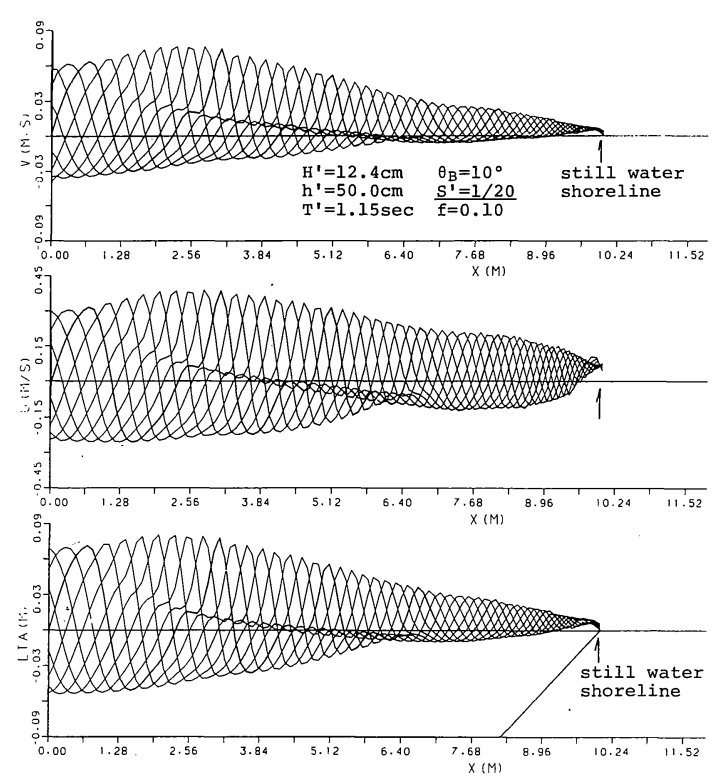

(c)

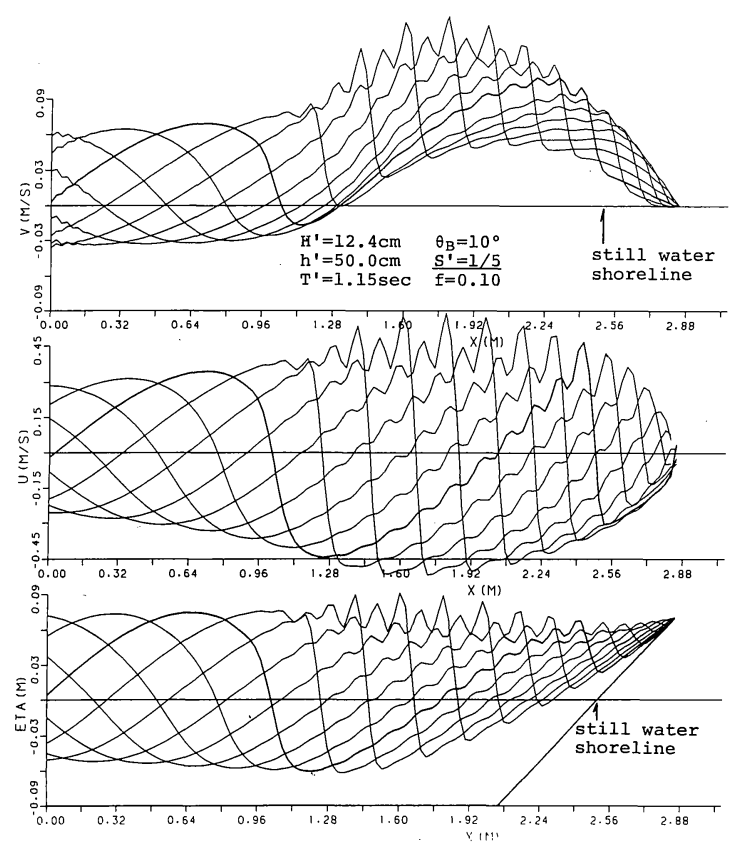

(d)

図一6 沿岸方向流速（上段）, 岸沖方向流速（中段）, 水位変動（下段）の空間波形

得た．本計算ではこれを考慮して各データセットに対し て $f^{\prime}$ を変化させることはせず, 0.05 と一定として計算 を行った.

図一2は Kamphuis の不規則波を用いた実験結果との 比較である. 実験結果は原論文中で砕波点と示した点よ り沖側ですでに波高が減少しており，計算結果よりかな り小さな值となった. Kamphuis の実験では移動床のた めに初期の一様勾配の状態より底面形状が変化していた

\section{ことも予想される.}

図一3 は Sato らの実験結果との比較を示したもので, 上段が平均水位，下段が波高変化に関するものである. 計算結果は実験結果に見られるような波高の増大を示し ておらず，砕波により波高減衰し始める点もかなり沖側 にある. 平均水位に関しては岸側端での最大值について はほぼ一致している。

図一4 は Stive-Wind の実験結果との比較を示したも 

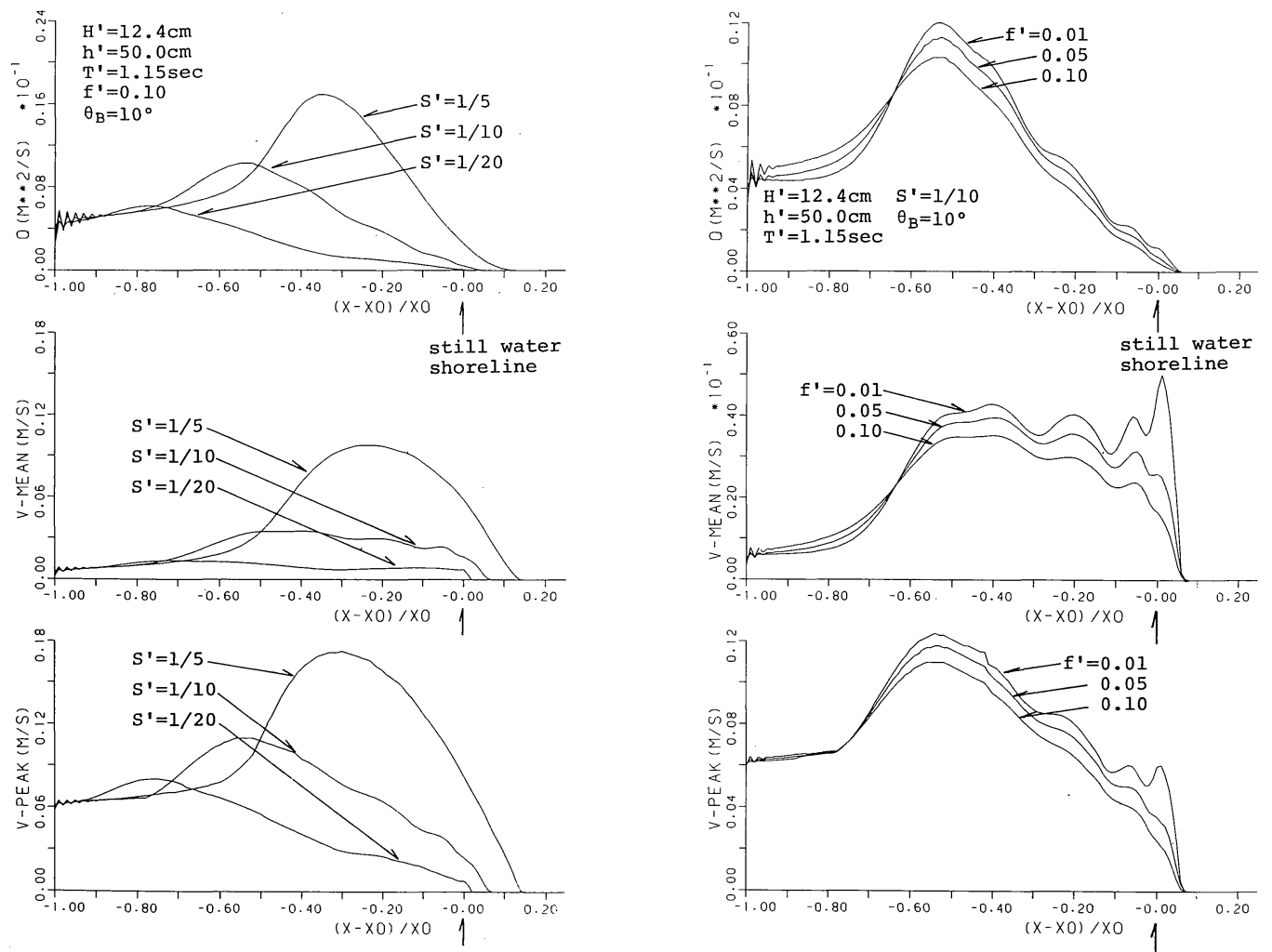

(a)

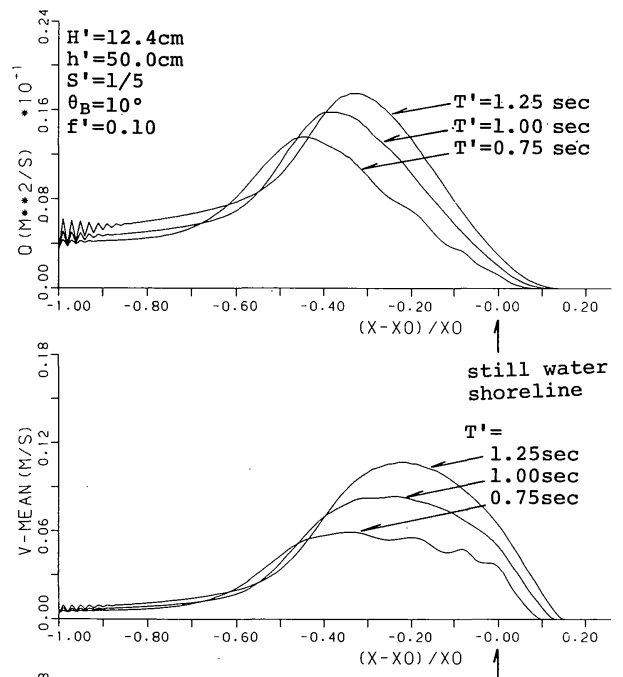

(c)

図一7 沿岸流速の極大值 $v_{\text {peak }}$ (下段), 平均値 $v_{\text {mean }}$ (中段), 沿岸流量 $Q$ (上段）の岸沖方向分布

ので, 波高変化および平均水位の大きさについて比較的 良い一致を見ている. 図一 3 に比べ図-4の一致が良い のは, Stive らの実験結果の再現が水深・波長比が小さ い条件で行っていることに起因すると考えられる. 非線 形長波理論によって水深の大きい沖側から浅水変形・砕 波減衰の全領域にわたってこれを厳密に表現する事はで きず，静水圧近似の可能な範囲に適用が限定される. 本 研究は汀線付近の沿岸方向流れに注目したものであり, 非線形長波理論の適用範囲を十分に踏まえた上で, 汀線 付近の流れ場を議論する必要がある.

\section{（2）計算結果とその特性}

数値計算の基礎式は無次元量で誘導したが, 計算結果 の表示は理解の容易さから次元量に戻して表示すること にする.

まず，計算結果の沖側端での無反射性を検討した。図 -5 は入射開始から 5 周期 10 周期目までの同一位相時 の水位変動 $\eta^{\prime}$, 岸沖方向流速 $u^{\prime}$ および沿岸方向流速 $v^{\prime}$

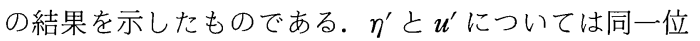

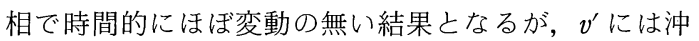
側端での反射が少し見られる.

(b) 


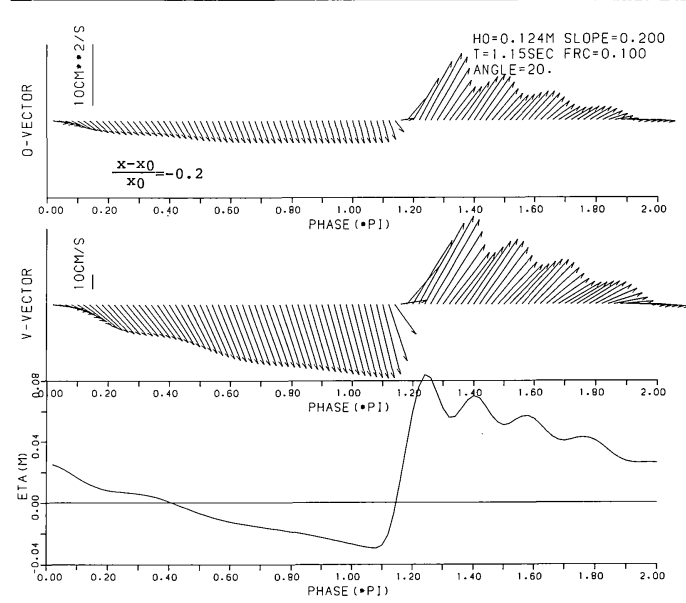

(a)

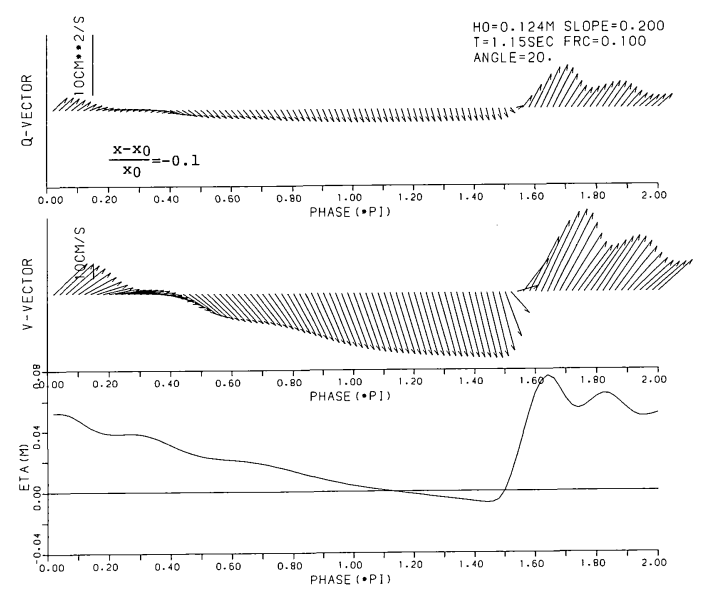

(b)

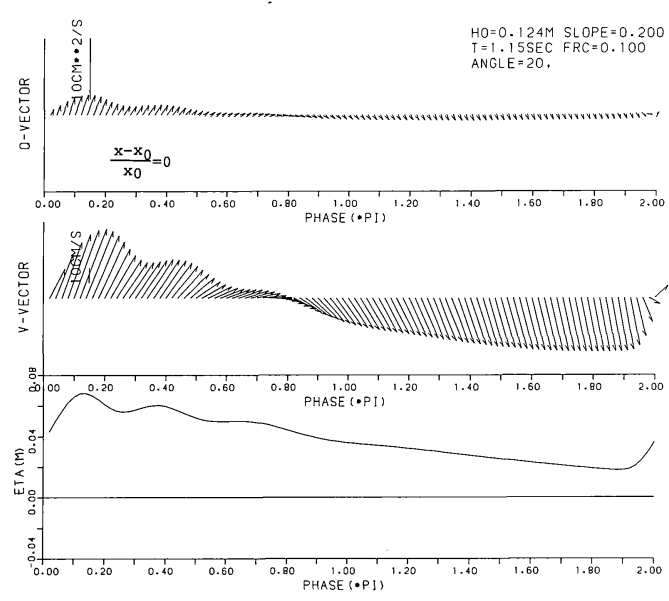

(c)

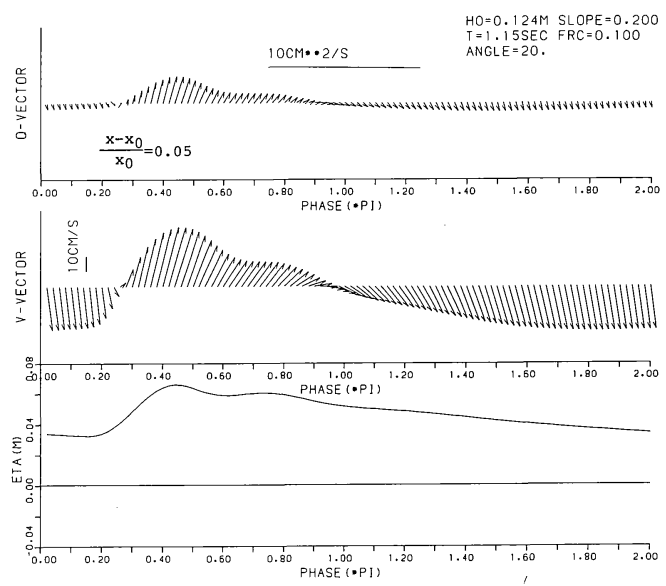

(d)

図一8 水位変動 $\eta^{\prime}$, 流速ベクトル $v^{\prime}$, 流量フラックス $Q^{\prime}$ の時間変化

計算は, 図一2 に示した Kamphuis の実験条件に近い諸 元で行った. すなわち, 沖側端の水深 $d_{B}^{\prime}$ を $0.5 \mathrm{~m}$ とし, 入射波は波高 $H^{\prime}=12.4 \mathrm{~cm}$, 周期 $T^{\prime}=1.15 \mathrm{~s}$ ，入射角 $\theta_{B}=10^{\circ}$ ，海底勾配 $S^{\prime}=1 / 10$ を基本条件とした．図一6 ( a ), ( b ) はその計算結果で海底摩擦係数 $f^{\prime}$ をそれ ぞれ 0.01 と 0.10 としたものである. 上段から順に沿岸 方向流速 $v^{\prime}$, 岸沖方向流速 $u^{\prime}$, 水位変動 $\eta^{\prime}$ の空間波形 を示している. 両図より, $\eta^{\prime}, u^{\prime}$ については摩擦係数に よる結果の差異がほとんど見られないのに対し，沿岸流 速については特に汀線付近において差異が生じ, 摩擦係 数が小さいほど沿岸流速は大きくなることがわかる.

図一（c）および (d) は，図一6（b）と同じ条件 で海底勾配 $S^{\prime}$ のみをそれぞれ $1 / 20$ と $1 / 5$ に変化させた 結果である，ただし，横軸は勾配によって縮尺を変化さ

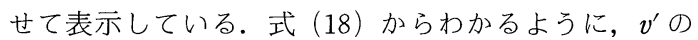
方程式に斜面勾配 $S^{\prime}$ は含まれず, 変動水深 $h^{\prime}$, 岸沖流 速 $u^{\prime}$ の変化を通じて間接的に $S^{\prime}$ の効果が $v^{\prime}$ に関与す
る. 図（c）から勾配が緩くなると，汀線近くの $v^{\prime}$ の 值が小さくなることがわかるが，これは斜面勾配が緩け れば，汀線到達時の波向角が 0へより漸近するためであ る. 一方，図 (d) のように勾配が急になると静水時汀 線よりも陸側でも大きな沿岸流速が生じることがわか る. また，斜面勾配 $S^{\prime}=1 / 10$ の図（a ），（b ）の結果 にも見られるが, 静水時汀線付近で沿岸流速 $v$ は波の谷 位相においても正の值を示し，この性質は斜面勾配が大 きい図 $(d)$ の結果ではその領域が広がり特に顕著とな る.すなわち遡上波の up rush 時のみならず down rush 時を通じても水粒子塊は沿岸方向の一方向に運ばれる.

次に計算された沿岸流速 $v^{\prime}$ の特性を調べるために, 時間変動する $v^{\prime}$ の極大值 $v_{\text {peak }}, v^{\prime}$ の平均值 $v_{\text {mean }}$ お び次式で定義される単位奥行き当たりの沿岸流の流量 $Q$ の岸沖方向分布を調べた。

$$
Q=\frac{1}{T} \int_{0}^{T} h^{\prime} v^{\prime} d t^{\prime}
$$


図一7（a）は，斜面勾配 $S^{\prime}$ をパラメターとした結果 で, 横軸は静水時の計算対象海浜幅 $x_{0}=d_{B}^{\prime} / S^{\prime}$ で無次元 化している. 図より, 斜面勾配が大きくなるとすべての 沿岸流速の特性量は大きくなり, その極大值は初期汀線 に近づくことがわかる．また無次元遡上距離も大きくな る. 図一7（b ） は周期 $T^{\prime}$ をパラメターとした結果で, 周期が長いほど沿岸流速の特性量が増加し, その極大值 は初期汀線に近づくことがわかる. 以上の特性は, 斜面 上の砕波形式や砕波後の波高減衰の違いに依拠している 亡考えられる. 図一7 (c) は摩擦係数 $f^{\prime}$ をパラメター とした結果である. $f^{\prime}$ が大きいほど $v^{\prime}$ の特性量は減少 することは当然であるが，その減少量は後述する既往の 公式から予測される值に比べて小さい.

なお，入射角 $\theta_{B}$ については $v^{\prime}$ を無次元化した式 (12) に微小パラメター $\epsilon$ が用いられていることからわかるよ うに, $\sin \theta_{B}$ に比例して上記の特性量は増減する.

Longuet-Higgins $(1970)^{16)}$ の沿岸流速の理論解は水 平拡散項を考慮しなければ次式で与えられる.

$$
V^{\prime}=1.57 \sqrt{g h_{b r}^{\prime}} S^{\prime} \sin \alpha_{b r} / f^{\prime}
$$

これより, 沿岸流速 $V^{\prime}$ は砕波水深 $h_{b r}^{\prime}$ の $1 / 2$ 乗, 斜面 勾配 $S^{\prime}$, 砕波時の波の入射角 $\sin \alpha_{b r}$ に比例し, 摩擦係 数 $f^{\prime}$ に反比例することがわかる. 上式を基に図一7に 示した結果を検討すると, $v^{\prime}$ は斜面勾配の増加にほぼ 比例して増加するが， $f^{\prime}$ のー1 乗に比例するような急激 な減少は示さない. また, $v^{\prime}$ の絶対值自身も水平拡散 項を無視した Longuet-Higgins の解の 1/5〜1/10 程度 となる。

図一8は初期汀線からの距離 $\left(x-x_{0}\right) / x_{0}$ の点におけ る水位変動 $\eta^{\prime}$ (下段), 流速ベクトル $\boldsymbol{v}^{\prime}$ (中段) および 単位幅当たりの流量フラックス $\boldsymbol{Q}^{\prime}$ (上段) の時間波形 を示したものである．計算条件は結果の特性を明示する ため, 斜面勾配 $S^{\prime}=1 / 5$, 波の入射角 $\theta_{B}=20^{\circ}$ 亡し, 他 の諸元はこれまでと同じとした. 図の（a）は初期汀線 から計算対象領域の長さ $x_{0}$ の $20 \%$ 沖側地点での結果 で, (b )，（c）の順に岸側となり，（d）は初期汀線よ り $0.05 x_{0}$ だけ岸側の結果である.これらの図の中段の $\boldsymbol{v}^{\prime}$ の結果を見ると, 峰位相では波は汀線に角度を持っ て遡上するが，谷位相では沿岸方向成分は小さくほぼ汀 線に直角下方に流下することがわかる. 遡上時には水深 $h^{\prime}$ が大きく, 流下時には $h^{\prime}$ が小さくなるため, 上段に 示した流量 $\boldsymbol{Q}^{\prime}$ の結果では，遡上時と流下時で方向のみ ならず $\boldsymbol{Q}^{\prime}$ の絶対値も差が大きくなる.この性質は岸側 の地点に行くほど顕著で, (d) の結果においては流下 時には微少な $\boldsymbol{Q}^{\prime}$ の值しか得られないことがわかる(図 (d）では $\boldsymbol{Q}^{\prime}$ の表示スケールを変えて示している).

漂砂を考える場合，掃流状態であれば流速ベクトル $\boldsymbol{v}^{\prime}$ が, 浮遊状態であれば流量フラックス $\boldsymbol{Q}^{\prime}$ が底質移動
の基本的外力となろう. 以上の遡上域の流れの性質は, 波打ち帯のジグザグ漂砂を記述する上での基礎的知見亡 なると考えられる。

\section{5. 結 語}

本研究はこれまでほとんど研究がなされなかった斜め 遡上波による平面 2 次元流体場を, Ryrie の方法に従っ て岸沖方向と沿岸方向の独立な方程式系に分離し, これ を準 1 次元的に計算することにより波打ち帯における流 れの特性を考察したものである.

その結果，沿岸方向流れは静水時汀線より沖側でも有 意な大きさを持ち, 斜面勾配, 入射波周期の増大ととも に沿岸流速の特性量は増大することがわかった。

平面的な遡上波の流速ベクトルおよび流量フラックス を調べたところ，遡上時には波は汀線に斜めに進行する が, 流下時には重力の作用により, 斜面にそって直角に 降下する傾向が明らかになった．流下時には水深が小さ くなることから, 流量フラックスは方向のみならず絶対 值も遡上時と流下時で大きく異なる結果となった. これ らの性質は波打ち帯でのジグザグ漂砂を記述する上でも 重要と考えられる.

本研究では遡上端を自由境界として解析するために非 線形長波理論を用いたが，この理論は水深・波長比が十 分小さい領域が適用範囲であり, 砕波帯内で発達する沿 岸流を精度良く表現するには，沖浜帯・砕波帯を通じて 適用できる波動理論を開発する必要がある. また実現象 では砕波あるいは先行の遡上波の引き波との干渉の結果 生じる乱れによる減衰が生起する. 波動モデルの高精度 化は今後の課題である. さらに平面水槽で波打ち帯の水 粒子速度の測定実験を行い, 数值計算結果と併せて平面 2 次元の遡上波の特性を実験的にも明らかにする必要が ある。

\section{参 考 文 献}

1) Bodge, K.R. and R.G. Dean : Short-term impoundment of longshore transport. Proc. of Coastal Sediment '87, pp.468 483, 1987.

2) Kamphuis, J.W. : Alongshore sediment transport rate distribution, Proc. of Coastal Sediment '91, pp.170 183, 1991.

3）宇多高明・山本幸次・河野茂樹 : 沿岸漂砂による 3 次元 海浜地形変化の予測法, 海岸工学論文集, 第 38 巻, pp.386 390, 1991.

4）佐藤慎司・M. Kabiling : Boussinesq 方程式を用いた波 浪 ·海浜流 - 海浜変形の数值計算, 海岸工学論文集, 第 40 巻 ( 1 ), pp. 386 390, 1993.

5) de Vriend H.J. and J.A. Ribberink : A quasi-3 D mathematical model of coastal morphology, Proc. of $21 \mathrm{st}$ Inter. Conf. of Coastal Engrg., pp.1689 1703, 1989.

6) Karambas, Th. V. and C. Koutitas : A breaking wave 
propagation model based on the Boussinesq equations, Coastal Engrg., Vol.18, pp.1 19, 1992.

7) Hibberd, S. and Peregrine, D.H. : Surf and run-up on a beach; A uniform bore, J. of Fluid Mech., Vol.95, pp.323 -345., 1979.

8) Kobayashi, N., A.K. Otta and I. Roy : Wave reflection and run-up on rough slopes, J. of Waterway, Port, Coastal and Ocean Div., ASCE, Vol.113, No.3, pp.282 298, 1987.

9) Ryrie, S.C. : Longshore motion generated on beaches by obliquely incident bores, J. Fluid Mech., Vol.129, pp.193 -212, 1983.

10）浅野敏之・中野武：斜め遡上波の数値解析, 海岸工学論 文集, 第 39 巻, pp. 26 30, 1992.

11) Kamphuis, J.W.: Wave transformation, Coastal Engineering, Vol.15, pp.173 184, 1991.

12) Sato, S., M. Fukuhama and K. Horikawa : Measurements of near-bottom velocities in random waves on a constant slope, Coastal Engrg., in Japan, Vol.31, No.2, pp.219 229, 1988.

13) Stive, M.J. F. and H.G. Wind : A study of radiation stress and set-up in the nearshore region, Coastal Engrg., Vol.6, pp.1 25, 1982.

14) Kobayashi, N., G.S. DeSilva and K.D. Watson : Wave transformation and swash oscillation on gentle and steep slopes, J. of Geophysical Res., Vol.94, No.C1, pp.951 966, 1989.

15）水口 優 - 小林敬一・奥山勝人・森田靖則：沿岸流にお ける粗度の効果に関する実験, 中央大学理工学部紀要, 第 22 巻, pp. 205 -219, 1979.

16) Longuet-Higgins, M. S. : Longshore current generated by obliquely incident sea waves, J. Geophys. Res., Vol.75, pp.6778 6801, 1970.

(1994.2.7 受付)

\section{LONGSHORE FLOWS IN SWASH ZONE DUE TO OBLIQUELY INCIDENT WAVES}

Toshiyuki ASANO

A numerical model is developed to predict the flow characteristics in a swash zone for obliquely incident wave trains. The two-dimensional shallow water equations are de-coupled into independent equations each for on-off shore motion and for longshore motion. A front of swash wave train is treated as a moving boundary to predict the motion for landward region of the still water shoreline. The results show non-vanishing longshore velocities and volume flux at the still water shoreline. These quantities are found to increase with the beach slope and incident wave period. The two-dimensional uprush and downrush motion near the front are found to be skew symmetric both in direction and in magnitude which may cause zig-zag longshore sediment transport inherent in swash zone. 